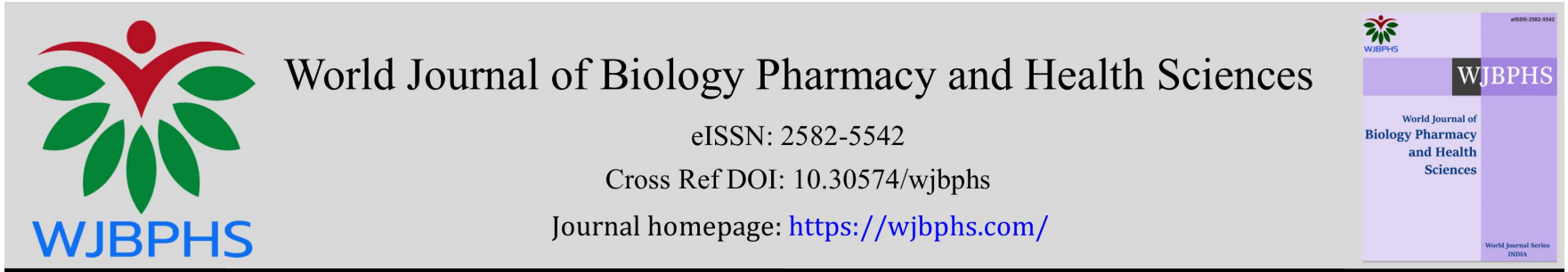

(RESEARCH ARTiCLE)

\title{
Effect of Ziziphus spina-christi and Cinnamomum zeylanicum essential oils on the microbiological quality of braided cheese during the storage period
}

\author{
Abdulaziz Yahya Al-Ghamdi ${ }^{1}$, Hanady Abdelateef Abdalla Khalefa ${ }^{2}$ and Mohamed Osman Mohamed Abdalla ${ }^{3, *}$ \\ ${ }^{1}$ Department of Biology, Faculty of Science, Albaha University, P.O. Box 1988, Al-Baha, Saudi Arabia. \\ 2 Department of Dairy Production, Faculty of Animal Production, University of Khartoum, Sudan. \\ 3 Department of Biology, Faculty of Science and Arts, Al-Makhwah 65931, Albaha University, Saudi Arabia.
}

World Journal of Biology Pharmacy and Health Sciences, 2021, 07(02), 001-008

Publication history: Received on 11 April 2021; revised on 14 may 2021; accepted on 17 May 2021.

Article DOI: https://doi.org/10.30574/wjbphs.2021.7.2.0053

\begin{abstract}
The purpose of this study was to understand how the addition of Ziziphus spina-christi and Cinnamomum zeylanicum essential oils as antimicrobial agents affect the microbiological properties of braided cheese. Cheese was made from warmed $\left(45^{\circ} \mathrm{C}\right)$ raw cow milk to which essential oils of Z. spina-christi and C. zeylanicum $(0.3 \%$ and $0.5 \%)$ were added. Microbiological characteristics were determined at 1, 7, 14 and 21-day intervals. The essential oils of Z. spina-christi and C. zeylanicum significantly reduced the counts of total viable bacteria (TVB), coliform bacteria, S. aureus, yeasts and moulds in cheese supplemented with the oils compared to the control cheese. As the concentration of oil increased, the number of microbes decreased. The storage period had a significant effect on the microbial counts in both the control cheese and the cheese supplemented with essential oils of Z. spina-christi and C. zeylanicum. The addition of the oils as preservatives to the braided cheese was effective against microbial populations and could be used in cheese preparations to extend the shelf life of cheese, particularly for cheese made from raw milk without the addition of starter culture.
\end{abstract}

Keywords: Braided cheese; Microbiological; Ziziphus spina-christi; Cinnamomum zeylanicum; Essential oil

\section{Introduction}

Food technology research continues to face significant challenges in finding effective ways to add value to produce foodstuffs while also maintaining their quality and safety [1]. However, the growing consumer demand for safe and natural products free of chemical preservatives has prompted food authorities and researchers to conduct extensive research into the feasibility of mild preservation techniques and to improve the microbial quality and safety of products while retaining their good nutritional and organoleptic properties [2]. As a result, new methods of reducing or eliminating foodborne pathogens are still required, possibly in conjunction with existing method and furthermore, the World Health Organization has recently called for a global reduction in salt consumption in order to reduce the prevalence of cardio-vascular disease [3].

Herbs and spices have been used since ancient times because of their antimicrobial properties, which increase food safety and shelf life by acting against foodborne pathogens and spoilage bacteria, and the plants have long been used in traditional medicine as a source of natural antimicrobial substances for the treatment of infectious diseases $[4,5]$. Several food preservation methods have been developed to ensure microbial food safety, as well as nutritional and sensory properties, however, consumer concern about health issues is driving up demand for natural antimicrobial agents [6]. In today's nutrition food system, dairy products are a unique carrier that has been successfully used to deliver phytochemicals and other nutrients for health benefits [7].

\footnotetext{
* Corresponding author: Mohamed Osman Mohamed Abdalla

Department of Biology, Faculty of Science and Arts, Al-Makhwah 65931, Albaha University, Saudi Arabia.
} 
Essential oils have long been used in the medical, cosmetic, and food industries. In recent years, extensive research has been conducted to investigate and determine the antimicrobial activity of essential oils [8]. Essential oils derived from medicinal herbs have numerous applications in ethnomedicine, cosmetics, food, beverages, preservation, fragrance, and pharmaceutical industries [9]. These oils have antioxidant, insecticidal, antiviral, antibacterial, antifungal, and antibiofilm properties [10].

The genus Zizphus is well-known for its antimicrobial, antioxidant, anti-inflammatory, and immune-stimulant properties [11]. The cinnamon oil contains antibacterial and antifungal compounds that can be used to prevent food spoilage due to microbial contamination [12]. To the best of our knowledge, no research reports on the antibacterial properties of $C$. zeylanicum and Z. spina-christi oils in cheese, as well as their possible mechanisms. This study was carried out to determine the effect of adding essential oil on the microbiological quality of braided cheese during the storage period.

\section{Material and methods}

\subsection{Extraction of essential oil from Z. spina-christi}

Powdered, dried seeds of Z. spina-christi (300 gm) were macerated with n-hexane at room temperature for $48 \mathrm{hr}$. The solvent was removed under reduced pressure to obtain the oil, which was sterilized by filtration through $0.45 \mu \mathrm{m}$ Millipore filters [13].

\subsection{Extraction of essential oil from C. zeylanicum}

Essential oil of C. zeylanicum was extracted from cinnamon barks using Clevenger apparatus. 100 gm of barks with 500 $\mathrm{ml}$ of distilled water was transferred into oil distillation at $90^{\circ} \mathrm{C}$ for $1-2 \mathrm{hr}$. The essential oil was collected and determined by calibrated tube, sterilized by filtration through $0.45 \mu \mathrm{m}$ Millipore filters, and kept in the freezer until used [12].

\subsection{Preparation of Solanum dubium extract}

The whole seeds were coarsely powdered using electric grinder, and $20 \mathrm{gm}$ of the powder were soaked in $100 \mathrm{ml}$ distilled water for $3 \mathrm{hr}$, followed by filtering, and $40 \mathrm{ml}$ of the liquid were used for the coagulation of milk.

\subsection{Manufacture of braided cheese}

Aseptically, milk ( $25 \mathrm{~L}$ ) was warmed to $45^{\circ} \mathrm{C}$, then S. dubium extract ( $2 \mathrm{ml} / 50 \mathrm{ml}$ ) was added. After 5 minutes the curd was tested by knife and then the curd was cooked and the whey was drained. The curd was divided evenly into 5 equal batches: Control, to which no essential oil is added, $0.3 \%(\mathrm{v} / \mathrm{w}$ ) of Z. spina-christi essential oil, $0.5 \%$ (v/w) of Z. spinachristi essential oil, $0.3 \%(\mathrm{v} / \mathrm{w})$ of C. zeylanicom essential oil and $0.5 \%(\mathrm{v} / \mathrm{w})$ of C. zeylanicom essential oil. The curd was mixed thoroughly and preserved at room temperature for $12 \mathrm{~min}$, followed by elasticity test. The curd was cooked and braided. Salt $(6 \% \mathrm{w} / \mathrm{w})$ was added to the whey, heat treated $\left(63^{\circ} \mathrm{C} / 30 \mathrm{~min}\right)$, and the cheese was preserved in the whey for $24 \mathrm{hr}$, after which cheese was preserved in the whey at $4^{\circ} \mathrm{C}$. Microbiological analyses were carried out at 1,7 , 14, and 21-day intervals.

\subsection{Microbiological examination}

\subsubsection{Preparation of serial dilutions}

For the preparation of serial dilutions, $11 \mathrm{gm}$ of cheese were weighed aseptically in a sterile mixer, and $99 \mathrm{ml}$ of sterile peptone water were added, and mixed for two minutes to make the first dilution $\left(10^{-1}\right)$, followed by preparation of serial dilutions for up to $10^{-8}$ using sterile peptone water [14].

\subsubsection{Total viable bacteria count}

The plate count agar (Himedia, M091) was used for the enumeration of TVB. The plates were incubated in an inverted position at $32 \pm 1^{\circ} \mathrm{C}$ for $48 \pm 3 \mathrm{hr}$, and the colonies were counted using a manual colony counter (scan 100) and recorded as $\mathrm{cfu} / \mathrm{gm}[15]$.

\subsubsection{Staphylococcus aureus count}

Mannitol salt agar (Micro master, DM160) was used for the enumeration for coagulase positive staphylococci. The plates were incubated in an inverted position at $37^{\circ} \mathrm{C}$ for $48 \mathrm{hr}$, and the typical colonies were counted with a manual colony counter (Scan 100) and recorded as cfu/gm [15]. 


\subsubsection{Coliform bacteria count}

MacConkey agar was used to determine the coliform count. The plates were incubated in an inverted position at $37^{\circ} \mathrm{C}$ for 48 hours, and the typical colonies were counted by a manual colony counter (Scan 100) and recorded as cfu/gm [16].

\subsubsection{Yeast and moulds count}

Yeast extract agar was used for the enumeration of yeasts and moulds. The plates were incubated in an inverted position at $25^{\circ} \mathrm{C}$ for 5 days, and the colonies were counted by a manual colony counter (Scan 100) and recorded as cfu/gm [17].

\subsection{Statistical analysis}

The statistical analysis was carried out using Statistical Analysis Systems (SAS, ver.9). General linear model (GLM) procedure was used to determine the effect of type and concentration of oil and the storage period on the microbiological characteristics of cheese. Duncan's multiple range test was conducted for mean separation between treatments $(P \leq 0.05)$.

\section{Results and discussion}

\subsection{Microbiological characteristics of cheese supplemented with Z. spina-christi and C. zeylanicum essential oils compared to control cheese}

Table 1 shows that TVB, coliform bacteria and $S$. aureus counts were significantly higher in the control cheese (log 10 $8.11 \pm 0.97 \mathrm{cfu} / \mathrm{gm}, \log _{10} 7.09 \pm 1.17 \mathrm{cfu} / \mathrm{gm}$ and $\log _{10} 5.18 \pm 1.63 \mathrm{cfu} / \mathrm{gm}$, respectively) and lower in cheese supplemented with $C$. zeylanicum essential oil $\left(\log _{10} 7.16 \pm 2.01 \mathrm{cfu} / \mathrm{gm}, \log _{10} 6.07 \pm 1.36 \mathrm{cfu} / \mathrm{gm}\right.$ and $\log _{10} 4.36 \pm 1.52 \mathrm{cfu} / \mathrm{gm}$, respectively).

Table 1 Effect of type of oil on the microbiological characteristics $\left(\log _{10} \mathrm{cfu} / \mathrm{gm}\right)$ of braided cheese (mean \pm SD)

\begin{tabular}{|l|l|l|l|l|}
\hline \multirow{2}{*}{ Microorganisms } & \multicolumn{3}{|c|}{ Type of oil } & \multirow{2}{*}{ SL } \\
\cline { 2 - 5 } & Control & Z. spina-christi & C. zeylanicum & \\
\hline Total viable bacteria & $8.11 \pm 0.97^{\mathrm{a}}$ & $8.03 \pm 0.86^{\mathrm{b}}$ & $7.16 \pm 2.01^{\mathrm{b}}$ & $* *$ \\
\hline Coliform bacteria & $7.09 \pm 1.17^{\mathrm{a}}$ & $6.50 \pm 0.66^{\mathrm{b}}$ & $6.07 \pm 1.36^{\mathrm{c}}$ & $* * *$ \\
\hline S. aureus & $5.18 \pm 1.63^{\mathrm{a}}$ & $4.58 \pm 1.51^{\mathrm{ab}}$ & $4.36 \pm 1.52^{\mathrm{b}}$ & $*$ \\
\hline Yeasts and moulds & $6.15 \pm 1.41^{\mathrm{a}}$ & $6.15 \pm 0.51^{\mathrm{a}}$ & $6.03 \pm 0.54^{\mathrm{a}}$ & NS \\
\hline
\end{tabular}

Although yeasts and moulds count was not significantly different between treatments, control cheese and cheese supplemented with Z. spina-christi essential oil showed higher count $\left(\log _{10} 6.15 \pm 1.41 \mathrm{cfu} / \mathrm{gm}\right.$ and $\log _{10} 6.15 \pm 0.51$ $\mathrm{cfu} / \mathrm{gm}$, respectively). These findings are consistent with Gupta et al. [18] who reported that C. zeylanicum oil was very effective against Bacillus sp., Listeria monocytogenes, E. coli, Klebsiella sp. and Rhizomucor sp., and Behbahani et al. [9] who reported an antibacterial activity of $C$. zeylanicum bark essential oil against Gram-positive bacteria (Listeria innocua, $S$. aureus, and B. cereus), compared to Gram-negative ones (E. coli, P. aeruginosa, and $S$. typhi) through disrupting cell envelope and facilitating the leakage of intracellular compounds. The oil extract of $Z$. spina-christi seed showed good antimicrobial activity against E. coli and Candida albicans, partially active against S. aureus, P. aeruginosa, and Aspergillus niger, and inactive against B. subtilis [19]. Abdel Karim et al. [13] reported that Z. spina-christi oil has a remarkable lethal effect on E. coli, $S$. typhimurium, and Aspergillus niger by inhibiting their survival. The essential oil of Z. spina-hristi was most sensitive to Aspergillus niger, Penicillium digitatum, and Klebsiella pneumonia, while P. aeruginosa, S. aureus, and B. cereus showed no sensitivity [20]. The oil of Z. spina-christi L. was found to be highly active against $S$. auras and Candida sp., and inactive against P. aeruginosa, B. subtilis and E. coli [21].

\subsection{Effect of concentration of the essential oil on the microbiological characteristics of cheese}

Table 2 shows that control cheese and cheese supplemented with $0.5 \%$ Z. spina-christi essential oil had the highest TVB count $\left(\log _{10} 8.11 \pm 0.97 \mathrm{cfu} / \mathrm{gm}\right.$ and $\log _{10} 8.12 \pm 0.69 \mathrm{cfu} / \mathrm{gm}$, respectively), while the lowest $\operatorname{count}\left(\log _{10} 6.80 \pm 2.71\right.$ 
$\mathrm{cfu} / \mathrm{gm}$ ) was in cheese supplemented with $0.5 \%$ C. zeylanicum essential oil. Coliform bacteria and S. aureus counts were significantly higher in control cheese ( $\log _{10} 6.84 \pm 0.85 \mathrm{cfu} / \mathrm{gm}$ and $\log _{10} 6.90 \pm 1.30 \mathrm{cfu} / \mathrm{gm}$, respectively) and lower in cheese supplemented with $0.5 \%$ C. zeylanicum essential oil $\left(\log _{10} 5.71 \pm 2.36 \mathrm{cfu} / \mathrm{gm}\right.$ and $\log _{10} 5.71 \pm 2.28 \mathrm{cfu} / \mathrm{gm}$, respectively). Yeasts and moulds count was significantly $(\mathrm{P}<0.01)$ higher in control cheese $\left(\log _{10} 8.15 \pm 1.04 \mathrm{cfu} / \mathrm{gm}\right)$, whereas no significant difference was observed in the other treatments. Research studies showed that Z. spina-christi var. aucheri essential oil inhibited the growth of Aspergillus niger, Penicillium digitatum, and Klebsiella pneumonia in concentrations of $32 \mathrm{gm} / \mathrm{ml}, 128 \mathrm{gm} / \mathrm{ml}$, and $512 \mathrm{gm} / \mathrm{ml}$, respectively [20]. Cinnamaldehyde, the main component of $C$. zeylanicum and C. cassia essential oils, was found to kill 99\% of Streptococcus pyogenes, Pseudomonas aeruginosa and E.

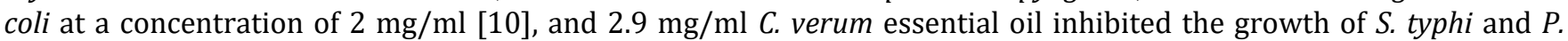
fluorescens [22]. C. burmannii bark essential oil has been shown to have antibacterial activity against $S$. aureus [23].

Table 2 Effect of concentration of oil on the microbiological characteristics $\left(\log _{10} \mathrm{cfu} / \mathrm{gm}\right)$ of braided cheese (mean \pm SD).

\begin{tabular}{|l|l|l|l|l|l|}
\hline \multirow{2}{*}{ Type of oil } & $\begin{array}{l}\text { Concentration } \\
\text { of oil (\%) }\end{array}$ & TVB & $\begin{array}{l}\text { Coliform } \\
\text { bacteria }\end{array}$ & S. aureus & $\begin{array}{l}\text { Yeasts and } \\
\text { moulds }\end{array}$ \\
\hline Control & 0 & $8.11 \pm 0.97^{\mathrm{a}}$ & $6.84 \pm 0.85^{\mathrm{a}}$ & $6.90 \pm 1.30^{\mathrm{a}}$ & $8.15 \pm 1.04^{\mathrm{a}}$ \\
\hline \multirow{2}{*}{ Z. spina-christi } & 0.3 & $7.94 \pm 0.60^{\mathrm{a}}$ & $6.43 \pm 0.76^{\mathrm{c}}$ & $5.49 \pm 2.25^{\mathrm{c}}$ & $6.86 \pm 0.65^{\mathrm{b}}$ \\
\cline { 2 - 6 } & 0.5 & $8.12 \pm 0.69^{\mathrm{a}}$ & $6.56 \pm 0.69^{\mathrm{b}}$ & $6.42 \pm 0.41^{\mathrm{b}}$ & $6.76 \pm 0.71^{\mathrm{b}}$ \\
\hline \multirow{2}{*}{ C. zeylanicum } & 0.3 & $7.52 \pm 2.19^{\mathrm{a}}$ & $6.42 \pm 0.59^{\mathrm{c}}$ & $6.27 \pm 1.05^{\mathrm{b}}$ & $6.75 \pm 0.66^{\mathrm{b}}$ \\
\cline { 2 - 6 } & 0.5 & $6.80 \pm 2.71^{\mathrm{b}}$ & $5.71 \pm 2.36^{\mathrm{d}}$ & $5.71 \pm 2.28^{\mathrm{c}}$ & $6.74 \pm 0.68^{\mathrm{b}}$ \\
\hline SL & \multicolumn{2}{|c|}{$* * *$} & $* * *$ & $* *$ \\
\hline
\end{tabular}

\subsection{Effect of storage period on the microbiological characteristics of cheese}

Table 3 shows the microbiological characteristics of control cheese during the storage period. TVB count decreased significantly $(\mathrm{P}<0.01)$ during the storage period, while coliform bacteria and yeasts and moulds counts increased until days 14 and then decreased towards the end, and $S$. aureus count gradually increased throughout the storage period.

Table 3 Effect of storage period on the microbiological characteristics ( $\left.\log _{10} \mathrm{cfu} / \mathrm{gm}\right)$ of control cheese (mean \pm SD).

\begin{tabular}{|l|l|l|l|l|l|}
\hline \multirow{2}{*}{ Microorganisms } & \multicolumn{4}{|c|}{ Storage period (days) } & \multirow{2}{*}{ SL } \\
\cline { 2 - 5 } & \multicolumn{1}{|c|}{$\mathbf{1}$} & \multicolumn{1}{|c|}{$\mathbf{7}$} & \multicolumn{1}{c|}{$\mathbf{1 4}$} & \multicolumn{1}{c|}{$\mathbf{2 1}$} \\
\hline Total viable bacteria & $8.48 \pm 0.11^{\mathrm{a}}$ & $8.38 \pm 0.92^{\mathrm{a}}$ & $7.98 \pm 1.54^{\mathrm{b}}$ & $7.59 \pm 0.46^{\mathrm{c}}$ & $* *$ \\
\hline Coliform bacteria & $5.95 \pm 0.31^{\mathrm{c}}$ & $6.65 \pm 0.75^{\mathrm{b}}$ & $7.57 \pm 0.12^{\mathrm{a}}$ & $7.20 \pm 0.96^{\mathrm{a}}$ & $*$ \\
\hline S. aureus & $5.09 \pm 0.99^{\mathrm{d}}$ & $6.83 \pm 0.37^{\mathrm{c}}$ & $7.40 \pm 0.34^{\mathrm{b}}$ & $8.27 \pm 0.30^{\mathrm{a}}$ & $* * *$ \\
\hline Yeasts and moulds & $6.92 \pm 1.02^{\mathrm{c}}$ & $8.00 \pm 0.41^{\mathrm{b}}$ & $8.94 \pm 0.32^{\mathrm{a}}$ & $8.74 \pm 0.39^{\mathrm{a}}$ & $*$ \\
\hline
\end{tabular}

The results of TVB contradict those of Cetinkaya and Soyutemiz [24], who reported an increasing trend of TVB count in Kaskar cheese during ripening. Cetinkaya and Soyutemiz [24] discovered an increasing pattern of yeasts and moulds content during ripening, which is consistent with the findings in this research.

TVB count of cheese supplemented with Z. spina-christi essential oil significantly $(\mathrm{P}<0.01)$ decreased during the storage period, while coliform bacteria count significantly $(\mathrm{P}<0.01)$ increased, and $S$. aureus and yeasts and moulds counts fluctuated during the storage period showing peaks on days 7 and 14, respectively (Table 4). 
Table 4 Effect of type of oil on the microbiological characteristics $\left(\log _{10} \mathrm{cfu} / \mathrm{gm}\right)$ of braided cheese during the storage period (mean \pm SD)

\begin{tabular}{|l|l|l|l|l|l|}
\hline \multirow{2}{*}{ Type of oil } & $\begin{array}{l}\text { Storage } \\
\text { period (days) }\end{array}$ & $\begin{array}{l}\text { Total viable } \\
\text { bacteria }\end{array}$ & $\begin{array}{l}\text { Coliform } \\
\text { bacteria }\end{array}$ & S. aureus & $\begin{array}{l}\text { Yeasts } \\
\text { moulds }\end{array}$ \\
\hline \multirow{4}{*}{ Z. spina-christi } & 1 & $8.69 \pm 1.06^{\mathrm{a}}$ & $5.96 \pm 0.31^{\mathrm{a}}$ & $5.09 \pm 0.14^{\mathrm{a}}$ & $6.92 \pm 0.25^{\mathrm{a}}$ \\
\cline { 2 - 6 } & 7 & $8.38 \pm 0.47^{\mathrm{b}}$ & $5.65 \pm 0.66^{\mathrm{b}}$ & $6.82 \pm 0.81^{\mathrm{b}}$ & $7.00 \pm 0.54^{\mathrm{a}}$ \\
\cline { 2 - 6 } & 14 & $7.98 \pm 1.01^{\mathrm{b}}$ & $5.56 \pm 0.92^{\mathrm{b}}$ & $6.02 \pm 0.4^{\mathrm{c}}$ & $7.94 \pm 0.32^{\mathrm{a}}$ \\
\cline { 2 - 6 } & 21 & $6.01 \pm 0.52^{\mathrm{c}}$ & $6.00 \pm 0.64^{\mathrm{a}}$ & $5.71 \pm 2.47^{\mathrm{d}}$ & $6.78 \pm 0.56^{\mathrm{b}}$ \\
\hline & SL & $* *$ & $* *$ & $* * *$ & $*$ \\
\cline { 2 - 6 } & 1 & $8.69 \pm 1.06^{\mathrm{a}}$ & $5.95 \pm 2.14^{\mathrm{a}}$ & $5.09 \pm 0.14^{\mathrm{c}}$ & $6.92 \pm 0.25^{\mathrm{a}}$ \\
\cline { 2 - 6 } C. zeylanicum & 7 & $7.74 \pm 0.58^{\mathrm{b}}$ & $5.53 \pm 0.84^{\mathrm{b}}$ & $5.29 \pm 0.85^{\mathrm{b}}$ & $5.81 \pm 0.54^{\mathrm{b}}$ \\
\cline { 2 - 6 } & 14 & $6.15 \pm 1.26^{\mathrm{d}}$ & $5.78 \pm 0.92^{\mathrm{b}}$ & $5.22 \pm 0.67^{\mathrm{b}}$ & $5.76 \pm 0.59^{\mathrm{b}}$ \\
\cline { 2 - 6 } & 21 & $6.74 \pm 3.03^{\mathrm{c}}$ & $5.55 \pm 0.75^{\mathrm{b}}$ & $5.51 \pm 2.19^{\mathrm{a}}$ & $5.71 \pm 0.52^{\mathrm{b}}$ \\
\cline { 2 - 5 } & SL & $* * *$ & $*$ & $* *$ & $*$ \\
\hline
\end{tabular}

Means in each column bearing similar superscripts are not significantly different $(\mathrm{p}>0.05) ;{ }^{*}=\mathrm{P}<0.05$;

$*^{* *}=\mathrm{P}<0.01 ; * * *=\mathrm{P}<0.001 ; \mathrm{SL}=$ Significance level; $\mathrm{SD}=$ Standard deviation

All microorganisms significantly decreased during the storage period of cheese supplemented with $0.3 \%$ and $0.5 \%$. spina-christi essential oil indicating an inhibitory effect of the oil against microbial population (Table 5). These findings are consistent with those of Nkafamiya et al. [25], who discovered that S. aureus was sensitive to Z. spina-christi oil. The findings, on the other hand, contradict the findings of Coopoosamy et al. [26], who reported that water extracts of leaves, roots, and stem bark of other species of $Z$. mucronata showed no activity against all Gram-negative and Gram-positive bacteria tested.

Table 5 Effect of concentration of oil on the microbiological characteristics (log10 cfu/gm) of braided cheese supplemented with $Z$. spina-christi during the storage period (mean \pm SD).

\begin{tabular}{|l|l|l|l|l|l|}
\hline $\begin{array}{l}\text { Concentration } \\
(\%)\end{array}$ & $\begin{array}{l}\text { Storage } \\
\text { period (days) }\end{array}$ & $\begin{array}{l}\text { Total viable } \\
\text { bacteria }\end{array}$ & $\begin{array}{l}\text { Coliform } \\
\text { bacteria }\end{array}$ & S. aureus & $\begin{array}{l}\text { Yeasts } \\
\text { moulds }\end{array}$ \\
\hline \multirow{5}{*}{$0.3 \%$} & 1 & $7.91 \pm 0.62^{\mathrm{a}}$ & $5.88 \pm 0.45^{\mathrm{c}}$ & $5.31 \pm 1.25^{\mathrm{b}}$ & $6.50 \pm 0.30^{\mathrm{c}}$ \\
\cline { 2 - 6 } & 7 & $7.81 \pm 0.41^{\mathrm{a}}$ & $6.32 \pm 0.22^{\mathrm{b}}$ & $6.86 \pm 0.32^{\mathrm{a}}$ & $7.34 \pm 0.55^{\mathrm{a}}$ \\
\cline { 2 - 6 } & 14 & $8.07 \pm 1.14^{\mathrm{a}}$ & $7.09 \pm 0.56^{\mathrm{a}}$ & $6.54 \pm 0.74^{\mathrm{a}}$ & $6.82 \pm 0.58^{\mathrm{b}}$ \\
\cline { 2 - 6 } & 21 & $7.97 \pm 0.40^{\mathrm{a}}$ & $6.42 \pm 0.60^{\mathrm{b}}$ & $3.25 \pm 3.47^{\mathrm{c}}$ & $6.78 \pm 0.61^{\mathrm{b}}$ \\
\cline { 2 - 6 } & SL & NS & $*$ & $* *$ & $*$ \\
\hline \multirow{3}{*}{$0.5 \%$} & $8.47 \pm 0.62^{\mathrm{a}}$ & $5.72 \pm 0.45^{\mathrm{c}}$ & $6.22 \pm 0.87^{\mathrm{c}}$ & $6.33 \pm 0.71^{\mathrm{c}}$ \\
\cline { 2 - 6 } & 7 & $7.87 \pm 0.41^{\mathrm{c}}$ & $6.80 \pm 0.67^{\mathrm{a}}$ & $6.93 \pm 0.60^{\mathrm{a}}$ & $7.03 \pm 0.54^{\mathrm{a}}$ \\
\cline { 2 - 6 } & 14 & $8.07 \pm 1.15^{\mathrm{b}}$ & $6.94 \pm 0.52^{\mathrm{a}}$ & $6.37 \pm 0.97^{\mathrm{b}}$ & $6.91 \pm 0.66^{\mathrm{b}}$ \\
\cline { 2 - 6 } & 21 & $8.05 \pm 2.75^{\mathrm{b}}$ & $6.79 \pm 0.78^{\mathrm{b}}$ & $6.17 \pm 0.49^{\mathrm{d}}$ & $6.79 \pm 0.46^{\mathrm{b}}$ \\
\cline { 2 - 5 } & SL & $* * *$ & $* *$ & $* *$ \\
\hline
\end{tabular}

Means in each column bearing similar superscripts are not significantly different $(\mathrm{p}>0.05) ;^{*}=\mathrm{P}<0.05{ }^{* *}=\mathrm{P}<0.01 ;^{* * *}=\mathrm{P}<0.001$ NS = Not significant; $\mathrm{SL}=$ Significance level; SD = Standard deviation .

Al-Mutairi et al. [27] reported that Z. spina-christi leaves extract had an inhibitory effect against all tested bacterial species. The ethanolic and butanolic extracts were bactericidal and bacteriostatic against E. coli, S. aureus, and C. albicans [28]. Z. spina-christi oil was found to have antibacterial activity against Staphylococcus aureus and E. coli [29].

Cheese supplemented with C. zeylanicum essential oil inhibited the growth of TVB, coliform bacteria, yeasts, and moulds, while the growth of $S$. aureus increased during storage (Table 4). Coliform bacteria, S. aureus, yeasts, and moulds counts 
significantly increased during the storage period of cheese supplemented with $0.3 \%$ C. zeylanicum essential oil, while TVB count decreased. However, the concentration of $0.5 \%$ C. zeylanicum essential oil had antimicrobial activity against microorganisms under study because the count decreased as the storage period progressed (Table 6). Previous research found no coliform bacteria, but yeasts, moulds, and $S$. aureus were found in trace amounts in some treated labneh containing $0.3 \%$ cinnamon oil [30]. The essential oil of $C$. zeylanicum significantly influenced $S$. aureus, Enterococcus, Enterobacter, and harmful fungi [31]. C. zeylanicum oil was found to have adequate antimicrobial activity against coliform bacteria [1]. The essential oil concentrations of 10, 20, and $30 \mu \mathrm{l} / \mathrm{ml}$ caused a rapid and steady decrease in the number of viable cells of Gram-positive and Gram-negative bacteria by 2 to 5 log cycles over 24 hours [12]. S. aureus counts in milk were reduced by $0.35-2.77 \mathrm{log} \mathrm{cfu} / \mathrm{ml}$ during storage, with significantly greater decreases observed when cinnamaldehyde was added, regardless of concentration, when compared to the control [32].

Table 6 Effect of concentration of oil on the microbiological characteristics $\left(\log _{10} \mathrm{cfu} / \mathrm{gm}\right)$ of braided cheese supplemented with $C$. zeylanicum during the storage period (mean $\pm \mathrm{SD}$ ).

\begin{tabular}{|c|c|c|c|c|c|}
\hline $\begin{array}{l}\text { Concentration } \\
(\%)\end{array}$ & $\begin{array}{l}\text { Storage } \\
\text { period (days) }\end{array}$ & $\begin{array}{l}\text { Total viable } \\
\text { bacteria }\end{array}$ & $\begin{array}{l}\text { Coliform } \\
\text { bacteria }\end{array}$ & S. aureus & $\begin{array}{l}\text { Yeasts and } \\
\text { moulds }\end{array}$ \\
\hline \multirow{5}{*}{$0.3 \%$} & 1 & $8.91 \pm 0.62^{\mathrm{a}}$ & $5.97 \pm 0.45^{b}$ & $5.16 \pm 1.25^{c}$ & $5.84 \pm 0.30^{c}$ \\
\hline & 7 & $7.17 \pm 0.41^{c}$ & $6.03 \pm 0.22^{b}$ & $6.50 \pm 0.32^{b}$ & $6.89 \pm 0.55^{b}$ \\
\hline & 14 & $8.06 \pm 1.14^{b}$ & $6.95 \pm 0.56^{\mathrm{a}}$ & $7.01 \pm 0.74^{a}$ & $7.23 \pm 0.58^{\mathrm{a}}$ \\
\hline & 21 & $5.93 \pm 0.40^{d}$ & $6.74 \pm 0.60^{\mathrm{a}}$ & $6.42 \pm 3.47^{b}$ & $7.04 \pm 0.61^{\mathrm{a}}$ \\
\hline & SL & * & * & $* *$ & $*$ \\
\hline \multirow{5}{*}{$0.5 \%$} & 1 & $7.59 \pm 0.62^{b}$ & $5.54 \pm 2.71^{c}$ & $5.78 \pm 0.48^{c}$ & $6.07 \pm 0.71^{b}$ \\
\hline & 7 & $7.32 \pm 0.41^{b}$ & $6.53 \pm 0.67^{b}$ & $7.07 \pm 0.60^{\mathrm{a}}$ & $6.98 \pm 0.54^{\mathrm{a}}$ \\
\hline & 14 & $8.24 \pm 1.15^{\mathrm{a}}$ & $7.42 \pm 0.52^{\mathrm{a}}$ & $6.38 \pm 0.97 \mathrm{~b}$ & $7.04 \pm 0.66^{\mathrm{a}}$ \\
\hline & 21 & $4.05 \pm 4.34^{c}$ & $6.36 \pm 0.78^{b}$ & $3.61 \pm 3.85^{\mathrm{d}}$ & $6.88 \pm 0.46^{\mathrm{a}}$ \\
\hline & SL & $* * *$ & $* *$ & ** & * \\
\hline
\end{tabular}

\section{Conclusion}

When compared to the control cheese, the essential oils of Z. spina-christi and C. zeylanicum inhibited the growth of microorganisms in cheese during storage. Microbial counts decreased as oil concentration increased. Traditionally, cheese is made from raw milk with no starter culture added; therefore, preservation methods such as the use of essential oils should be tried, provided that the question of cheese acceptability to consumers is answered through sensory analysis of cheese.

\section{Compliance with ethical standards}

\section{Acknowledgments}

The authors would like to acknowledge the assistance of the technical staff of the microbiology laboratory, Department of Dairy Production, Faculty of Animal Production, and University of Khartoum.

\section{Disclosure of conflict of interest}

The authors declare no conflict of interest.

\section{References}

[1] Cui HY, Zhou H, Lin L, Zhao CT, Zhang XJ, Xiao ZH, Li CZ. Antibacterial activity and mechanism of cinnamon essential oil and its application in milk. Journal of Animal and Plant Sciences. 2016; 26(2): 532-541. 
[2] Kuang XB, Li R, Kuang X, Zheng D, Zhu B, Xu B, Ma MH. Granularity and antibacterial activities of ultra-fine cinnamon and clove powders. Journal of Food Safety. 2011; 31: 291-296.

[3] Burt S. Essential oils: their antibacterial properties and potential applications in foods-a review. International Journal of Food Microbiology. 2004; 94: 223-253.

[4] Nabavi SF, Lorenzo AD, Izadi M, Sobarzo-Sánchez E, Daglia M, Nabavi SM. Antibacterial Effects of cinnamon: from farm to food, cosmetic and pharmaceutical industries. Nutrients. 2015; 7(9): 7729-7748.

[5] El-Sayed SM, Youssef AM. Potential application of herbs and spices and their effects in functional dairy products. Heliyon. 2019 Jun 1;5(6): e01989.

[6] Emiliano J, Quinto, Irma Caro, Luz H, Delgado V, Mateo J, De-Mateo-Silleras B, Redondo-Del-Río MP. Food safety through natural antimicrobials. Antibiotics. 2019; 8: 208.

[7] El-Sayed SM, Salama H, El-Sayed MM. Preparation and properties of functional milk beverage fortified with kiwi pulp and sesame oil. Research Journal of Pharmaceutical, Biological and Chemical Sciences. 2015; 6(5): 609-618.

[8] Kaskatepe B, Kiymaci ME, Simsek D, Erol HB, Erdem SA. Comparison of the Contents and Antimicrobial Activities of Commercial and Natural Cinnamon Oils. Indian Journal of Pharmaceutical Sciences. 2016; 78(4): $541-548$.

[9] Behbahani BA, Falah F, Arab FL, VasieeM, Yazdi FT. Chemical composition and antioxidant, antimicrobial, and antiproliferative activities of Cinnamomum zeylanicum bark essential oil. Evidence-Based Complementary and Alternative Medicine. 2020; Article ID 5190603, 8.

[10] Firmino DF, Cavalcante TTA, Gomes GA, Firmino NCS, Rosa LD, de Carvalho MG, Catunda Jr FEA. Antibacterial and antibiofilm activities of Cinnamomum Sp. essential oil and cinnamaldehyde: antimicrobial activities. The Scientific World Journal. 2018; Article ID 7405736.

[11] Saied AS, Gebauer J, Hammer K, Buerkert A. Ziziphus spina-christi (L.) Willd: a multipurpose fruit tree. Genetic Resources and Crop Evolution. 2008; 55: 929-937.

[12] Al-fekaiki DF, Niamah AK, Al-Sahlany STG. Extraction and identification of essential oil from Cinnamomum zeylanicum barks and study the antibacterial activity. Journal of Microbiology, Biotechnology and Food Sciences. 2017; 7 (3): 312-316.

[13] Abdel Karim M, Asma MH, Mustafa SK. GC-MS analysis and antimicrobial activity of Sudanese Ziziphus spinachristi (Rhamnaceae) fixed oil. International Journal of Research in Pharmacy and Pharmaceutical Sciences. 2017; 2(4): 83-87.

[14] Harrigan WF. Laboratory Methods in Food Microbiology. 3rd edition. London, England: Academic Press Ltd; 1998.

[15] Houghtby AG, Maturin LJ, Koenig KE. Microbiological Count Methods. In: Marshal RT, ed. Standard Methods for the Examination of Dairy Products. 16th Edn. Washington, DC, USA: American Public Health Association; 1992. P. 213-246.

[16] Christen LG, Davidson PM, McAllister JS, Roth LA. Coliform and Other Indicator Bacteria In: Marshal RT, ed. Standard Methods for the Examination of Dairy Products. 16th Edn. Washington, DC, USA: American Public Health Association; 1992. P. 247-269.

[17] Frank FJ, Christen GL, Bullerman LB. Tests for Groups of Microorganisms. In: Marshal RT, ed. Standard Methods for the Examination of Dairy Products. 16th Edn. Washington, DC, USA: American Public Health Association; 1992. P. 271-286.

[18] Gupta C, Garg AP, Uniyal RC, Kumari A. Comparative analysis of the antimicrobial activity of cinnamon oil and cinnamon extract on somefood-borne microbes. African Journal of Microbiology Research. 2008; 2(9): 247-251.

[19] Ahamed EMM. Characterization and biological activity study of Ziziphus spina-christi seed oil [Ph.D.]. Khartoum, Sudan: Sudan University of Science and Technology. 2016.

[20] Fard MPM, Ketabchi S, Farjam MH. Chemical composition, antimicrobial and antioxidant potential of essential oil of Ziziphus spina-christi var. aucheri grown wild in Iran. Journal of Medicinal Plants and By-products. 2020; 1: 6973.

[21] Fath El-Rahman A, Munged I, Tegani A, Ibrahim A, Mohamed A, Mohamed H, Mubarak A. Fatty acid composition and biological activity of Zizyphus spina-christi L. seeds oil from Sudan. International Journal of Engineering and Applied Science. 2019; 6(11): 21-23. 
[22] Naveed R, Hussain I, Tawab A, Tariq M, Rahman M, Hameed S, Mahmood MS, Siddique AB, Iqbal M. Antimicrobial activity of the bioactive components of essential oils from Pakistani spices against Salmonella and other multidrug resistant bacteria. BMC Complementary and Alternative Medicine. 2013; 13: 265-275.

[23] Hakim ML, Susilowati S, Effendi MH, Witaningrum AM. The effectiveness of antibacterial essential oil of cinnamon (Cinnamomum burmannii) on Staphylococcus aureus. Ecology, Environment and Conservation. 2016; 26(11): S276-S280.

[24] Centinkaya F, Soyutemiz GE. Microbiological and chemical throughout the manufactured and ripening of Kashar: a traditional Turkish cheese. Turkish Journal of Veterinary and Animal Sciences. 2006; 30(4): 397-404.

[25] Nkafamiya II, Shagal MH, Haruna M. Potential of Ziziphus spina-christi seed ethanolic extract on inhibition of microbial growth. Academia Journal of Biotechnology. 2013; 1(4): 053-056.

[26] Coopoosamy RM, Naidoo KK, Ndlazi NJ. Cultural importance and antibacterial activity of Ziziphus mucronata (Willd.) in the Umlazi community in Durban. African Journal of Pharmacy and Pharmacology. 2011; 5(17): 19791982.

[27] Al-Mutairi MH, Ali S, Aly SM, Aldebasi Y. Antibacterial activity of sider (Ziziphus spina- christi), leaves extract against selected pathogenic bacteria. European Journal of Pharmaceutical and Medical Research. 2016; 3(5): 138144.

[28] Alomari AA, Fadlelmula AA, Abdalla MOM. Evaluation of the antibacterial and antifungal activities and phytochemical screening of bark extract of Ziziphus spina christi L. (ZSC) in Albaha Area. Journal of Chemical, Biological and Physical Sciences. 2016; 7(1): 077-086.

[29] Bukar AM, Kyari MZ, Gwaski PA, Gudusu M, Kuburi FS, Abadam YI. Evaluation of phytochemical and potential antibacterial activity of Ziziphus spina-christi L. against some medically important pathogenic bacteria obtained from University of Maiduguri Teaching Hospital, Maiduguri, Borno State - Nigeria. Journal of Pharmacognosy and Phytochemistry. 2015; 3(5): 98-101.

[30] Thabet HM, Nogaim QA, Qasha AS, Abdoalaziz O, Alnsheme N. Evaluation of the effects of some plant derived essential oils on shelf-life extension of Labneh. Merit Research Journal of Food Science and Technology. 2014; 2(1): 008-014.

[31] Urbaniak A, Glowacka A, Kowalczyk E, Lysakowska M, Sienkiewicz M. The antibacterial activity of Cinnamon oil on the selected gram-positive and gram-negative bacteria. Medycyna Doswiadczalna I Mikrobiologia. 2014; 66(2): 131-141.

[32] Babic M, Glisic M, Zdravkovic N, Djordjevic J, Velebit B, Ledina T, Baltic MZ, Boskovic M. Inhibition of Staphylococcus aureus by cinnamaldehyde and its effect on sensory properties of milk. IOP Conf. Series: Earth and Environmental Science. 2019; 333: 012042. 